\title{
DETERMINAN PRAKTIK INTERNET REPORTING OLEH PEMERINTAH DAERAH DI INDONESIA
}

\author{
Hafiez Sofyani dan Vicky Dwirama \\ Program Studi Akuntansi Universitas Muhammadiyah Yogyakarta \\ hafiez.sofyani@umy.ac.id
}

\begin{abstract}
ABSTRAK
Penelitian ini bertujuan untuk menguji pengaruh Kompetisi politik, Kekayaan Daerah, Opini Audit, Akuntabilitas Kinerja terhadap Internet Reporting Pemerintah Daerah di Indonesia. Metode penelitian ini menggunakan metode deskriptif. Populasi pada penelitian ini terdiri dari 415 Pemerintah Daerah level Kabupaten dan 93 level kota pada tahun 2017. Penelitian ini menggunakan data sekunder. Pengujian hipotesis dalam penelitian ini menggunakan regresi linier berganda. Data yang telah dikumpulkan dianalisis terlebih dahulu dengan pengujian asumsi klasik kemudian dilakukan pengujian hipotesis dengan alat uji SPSS 21.0. Berdasarkan hasil penelitian dapat disimpulkan bahwa kompetisi politik, kekayaan daerah, dan opini audit berpengaruh positif terhadap Internet Reporting di Pemerintah Daerah. Diskusi dari hasil temuan disajikan di dalam paper ini.
\end{abstract}

\section{Kata Kunci: Kompetisi politik, Kekayaan Daerah, Opini Audit, Akuntabilitas Kinerja, Internet Reporting}

\section{PENDAHULUAN}

Undang-undang Republik Indonesia Nomor 14 tahun 2008 tentang keterbukaan informasi publik menyatakan bahwa pemerintah bertanggungjawab dalam memberikan informasi publik dengan efektif dan efisien. Berdasarkan Undang-undang tersebut, semakin besar tuntutan pemerintah dalam pelaksanaan akuntabilitas dan transparansi. Perkembangan teknologi informasi memberikan opsi bagi pemerintah untuk melaksanakan akuntabilitas dan transparansi melalui internet. Survei yang dilakukan Asosiasi Penyelenggara Jasa Internet Indonesia (APJII) menyebutkan bahwa pengguna internet Indonesia tahun 2016 mencapai 132,7 juta atau setara $51,7 \%$ terhadap populasi 256,2 juta jiwa. Hal ini menunjukkan bahwa internet menjadi kebutuhan yang penting bagi masyarakat. Survei juga menyebutkan konsumsi pengguna tentang berita, masuk tiga besar konten internet yang dicari dengan angka 127,9 juta (96,4\%) (Buletin APJII, 2016). Berdasarkan data tersebut dapat dikatakan bahwa internet selain menjadi kebutuhan penting, juga digunakan untuk mengakses informasi-informasi mengenai pemerintahan. Masyarakat sendiri dapat mengakses informasi-informasi mengenai pemerintahan yaitu di Website pemerintah daerah. Meskipun demikian, nampaknya pemerintah daerah belum memaksimalkan websitenya sebagai pemberi informasi-informasi mengenai pemerintahannya.

Sejauh ini praktik yang dilakukan pemerintah daerah pada website dalam memberikan informasi telah berjalan. Akan tetapi, terdapat beberapa pemerintah daerah yang belum memberikan informasi secara lengkap seperti laporan keuangan dan kinerja (Internet Reporting) pada website pemerintah daerah. Hal 
ini sesuai dengan penelitian Trisnawati dan Achmad (2014) yang menemukan bahwa tidak seluruh pemda mempublikasikan laporan keuangannya secara lengkap tiap tahunnya. Sedangkan, untuk menjadi pemerintah daerah yang memiliki good governance yang baik, Pemerintah daerah harus akuntabel dan transparan.

Pada era teknologi masa kini penggunaan internet adalah sarana yang murah dan mudah dalam memberikan informasi. Internet dapat dimanfaatkan dalam menunjukan transparansi dan akuntabilitas bagi pemerintah daerah. Internet juga digunakan oleh pemerintah daerah dalam mengungkapkan pertanganggungjawaban secara sukarela dan konkrit dalam mewujudkan akuntabilitasnya (Febrianty dan Jatmiko, 2011). Dengan adanya internet reporting maka akan meningkatkan kepercayaan masyarakat atas pelaksanaan akuntabilitas dan transparansi. Akan tetapi faktanya di lapangan tidak semua pemerintah daerah memanfaatkan fasilitas internet untuk menyampaikan informasi wajib maupun sukarela. Hal ini mengindikasikan adanya alasan atau determinan yang membuat pemerintah daerah melakukan internet reporting dan tidak.

Merujuk pada penelitian Nosihana dan Yaya (2016) tentang faktor-faktor yang mempengaruhi praktek Internet financial reporting, ditemukan bahwa kompetisi politik berpengaruh terhadap publikasi laporan keuangan di internet. Hal ini sejalan pula dengan hasil penelitian Rahman (2013) yang menyimpulkan bahwa semakin tinggi kompetisi politik, maka pemerintah daerah akan semakin intens untuk menggunakan internet sebagai sarana pelaporan informasi keuangan. Selain kompetisi politik, kekayaan daerah juga menjadi salah satu faktor yang mempengaruhi internet reporting. Hasil dari penelitian Rahman (2013) menyimpulkan bahwa kekayaan daerah berpengaruh positif terhadap pelaporan informasi keuangan Pemda. Akan tetapi hal ini tidak sejalan dengan hasil penelitian Hudoyo (2014) yang menemukan bahwa kekayaan daerah tidak berpengaruh terhadap pelaporan keuangan di internet. Tingkat kekayaan daerah yang besar menjadikan pemerintah pusat harus memperhatikan kinerja Pemerintah daerah dengan pelaksanaan audit oleh BPK. Karenanya fokus pemerintah daerah akan lebih tertuju pada pemenuhan ekspektasi hasil audit yang baik ketimbang transparansi dan akuntabilitas di media internet.

Selain dua variabel di atas, terdapat pula faktor lain yang mempengaruhi praktik internet reporting oleh pemda, yakni opini audit. Pada penelitian Hilmi dan Martani (2012) disimpulkan bahwa temuan audit berpengaruh positif terhadap pelaporan informasi keuangan. Temuan audit akan berdampak pada opini audit yang diterima pemda. Opini yang bagus akan menjadi sinyal positif pemerintah daerah, dan kemudian akan cenderung dilaporkan di website pemerintah daerah. Sebaliknya, opini audit yang kurang menguntungkan cenderung untuk ditutupi dan tidak disampaikan pada media internet. Akan tetapi hasil riset Hilmi dan Martini (2012) berbeda dengan Khasanah (2014) yang menemukan bahwa temuan audit tidak berpengaruh positif terhadap Pelaporan Keuangan.

Sejauh ini penelitian mengenai internet reporting di pemerintah daerah di Indonesia masih sangat jarang dilakukan (Styles dan Tennyson, 2007). Karenanya penelitian mengenai isu ini masih sangat penting untuk dilakukan supaya mendapatkan insight yang kaya dan kuat, khususnya mengenai determinan praktik internet reporting di pemerintah daerah di Indonesia. Diharapkan penelitian ini 
dapat memberikan gambaran kepada masyarakat dan pengguna informasi mengenai akuntabilitas dan transparansi pemerintah daerah. Selain itu dapat memotivasi pemerintah daerah dalam melaksanakan akuntabilitas dan transparansi pemerintah daerah melalui internet guna mencapai cita-cita good governance. Secara teori, penelitian ini berkontribusi dalam pengembangan teori stewardship dan signaling dalam konteks studi akuntansi sektor public, apakah teori ini relevan atau tidak dalam menjelaskan fenomena yang terjadi.

\section{TINJAUAN PUSTAKA DAN PENGEMBANGAN HIPOTESIS Teori Stewardship}

Teori Stewardship menggambarkan suatu situasi dimana para manajer tidak termotivasi pada tujuan-tujuan inividu seperti materi dan uang melainkan lebih ditekanan pada sasaran hasil utama mereka untuk kepentingan organisasi (Raharjo, 2007). Teori ini menjelaskan bahwa terdapat suatu hubungan yang kuat antara kepuasan dan kesuksesan suatu organisasi. Pada saat kepuasan dan kesuksesan organisasi telah terpenuhi maka pada akhirnya akan memaksimumkan kepentingan individu yang ada pada kelompok organisasi tersebut. Pada hal ini stewards yang digambarkan sebagai pemerintah memiliki hubungan dengan principal yang digambarkan sebagai masyarakat. Dengan adanya hubungan ini pemerintah yang memiliki informasi diharapkan mewujudkan transparansi dan akuntabilitasnya kepada masyarakat sesuai dengan harapan dan kepercayaan yang telah diberikan rakyat. Akuntansi organisasi sektor publik sendiri telah dipersiapkan untuk memenuhi kebutuhan informasi untuk hubungan steward dan principal. Posisi pemerintah sebagai steward memiliki kaitan dengan argumentasi pada teori signaling, dimana sudah sepatutnya seorang steward memberikan informasi kepada para pemangku kepentingan sebagai sinyal positif terkait kepemimpinan yang dijalankannya. Tujuannya adalah untuk melegitimasi kepemimpinan yang diemban dan menjaga stabilitas elektabilitas pemimpin daerah secara politis (Connelly et al., 2011).

\section{Teori Signalling}

Teori signalling menjelaskan pemerintah sebagai pihak yang diberikan amanah kepada masyarakat yang berkeinginan menunjukkan signal kepada masyarakat. Signal pemerintah kepada masyarakat adalah dengan memberikan informasi-informasi baik keuangan maupun kinerja yang mereka lakukan pada website pemda. Hal ini dilakukan atas amanat yang telah diberikan oleh masyarakat kepada pemerintah. Dalam konteks ini pemerintah berusaha memberikan sinyal baik kepada masyarakat (Evans dan Patton 1987). Hal ini bertujuan agar masyarakat dapat terus mendukung pemerintah yang sedang berjalan sehingga pemerintahan dapat berjalan dengan baik. Kinerja pemerintahan yang baik dapat diinformasikan kepada masyarakat dalam bentuk pertanggungjawaban maupun promosi untuk tujuan politik. Sarana internet menjadi sangat relevan sebagai media transparansi serta akuntabilitas pada era desrupsi sekarang. Karenanya, internet reporting dapat dipandang sebagai upaya pemberian sinyal positif pemerintah daerah kepada para pemangku kepentingan atas amanah kepemimpinan yang tengah mereka emban. 


\section{Kompetisi Politik terhadap Internet reporting}

Pada penelitian Rahman (2013) menyebutkan bahwa internet merupakan sarana yang paling mudah dan murah bagi pemerintah dalam melaporkan informasi keuangan dan kerja sebagai bukti kinerja mereka kepada masyarakat. Sesuai dengan teori signalling yang menjelaskan pemerintah sebagai pihak yang diberikan amanah kepada masyarakat yang berkeinginan menunjukkan signal kepada masyarakat. Intruksi Mendagri Nomor 188.52/1797/SJ telah mengatur pedoman pelaporan anggaran pemda yang transparan dan akuntabel, intruksi ini mewajibkan pemda untuk memberikan informasi anggaran melalui website masing-masing pemda. Hal ini menyebabkan pemerintah akan berhati-hati dalam melaporkan keuangan dan kinerja mereka pada website pemda. Hasil penelitian yang dilakukan oleh Rahman (2013) menyimpulkan bahwa kompetisi politik berpengaruh positif terhadap internet reporting. Menurut Rahman (2013) Semakin tinggi kompetisi politik, kecenderungan pemerintah daerah untuk menggunakan internet sebagai sarana pelaporan informasi keuangan yang mudah dan murah juga akan semakin tinggi. Internet merupakan sarana yang mudah dan murah bagi pemerintah daerah dalam melakukan pelaporan informasi mengenai kinerja dan keuangannya. Dengan adanya bukti bahwa pemerintah telah melakukan transparansi dan akuntabilitas, diharapkan kepercayaan masayarakat akanmeningkat dan elektabilitas pemerintah daerah dapat terjaga. Dengan kepercayaan masyarakat tersebut pejabat terpilih akan berekspektasi untuk memenangkan pemilu diperiode berikutnya (Nurrizkiana et al., 2017).

\section{$\mathrm{H}_{1}$ : Kompetisi politik berpengaruh positif terhadap internet reporting}

\section{Kekayaan Daerah terhadap Internet Reporting}

Kekayaan daerah dapat didefinisikan sebagai seberapa besar pendapatan asli daerah dari suatu daerah (Nosihana \& Yaya 2016). PAD merupakan sumber keuangan yang berasal dari daerah itu sendiri. Dengan demikian kekayaan daerah yang tinggi dapat dilihat dari tingginya PAD suatu daerah. PAD akan menunjukkan kinerja pemerintah daerah dalam mengelola pendapatannya dengan baik. Dengan demikian pemda akan berusaha menunjukkan kepada stakeholders sebagai signal bahwa telah mengelola kekayaan daerah dengan baik. Hilmi dan Martani (2012) menyatakan bahwa kekayaan daerah berpengaruh positif terhadap tingkat pelaporan keuangan pemerintah provinsi. Peningkatan pengungkapan terjadi ketika pemerintah provinsi memiliki kekayaan yang lebih besar yang dapat digunakan untuk melakukan pengungkapan. Dengan demikian, jika terungkapnya kekayaan daerah pada pengungkapan, maka masyarakat akan memberikan kepercayaan mereka. Melihat potensi ini, maka diprediksi pemerintah daerah akan sukarela dalam melaporkan segala yang berkaitan dengan kekayaan daerah yang dilihat dari PAD yang besar melalu internet agar masyarakat dapat melihat kinerja yang baik dari pemerintah daerah (Puspita \& Martani, 2010).

\section{$\mathrm{H}_{2}$ : Kekayaan daerah berpengaruh positif terhadap internet reporting}

\section{1}




\section{Opini Audit terhadap Internet Reporting}

Trisnawati dan Achmad (2014) menyebutkan bahwa Opini audit adalah salah satu indikator kualitas akuntabilitas keuangan dilihat atas Laporan Keuangan Pemerintah Daerah (LKPD). Opini audit yang diberikan kepada pemerintah daerah akan mempengaruhi tingkat pengungkapan laporan keuangan dan kinerja pemda. Pemda yang mendapatkan hasil opini audit WTP biasanya akan lebih cenderung untuk mempublishkan laporan keuangannya agar masyarakat mengetahui bagaimana kinerja Pemda tersebut (Trisnawati dan Achmad, 2014). Pada penelitian Hilmi dan Martani (2012) menyatakan bahwa tingkat penyimpangan memiliki pengaruh positif terhadap tingkat pengungkapan laporan keuangan. Dengan demikian pemda cenderung untuk memberikan informasi yang dimiliki di internet. Hal ini menunjukkan pemerintah memberikan signal kepada masyarakat bahwa telah melaksanakan amanah yang diberikan oleh masyarakat.

Laporan keuangan pemda yang telah di audit dan mendapatkan predikat tidak wajar, maka akan membuat pemerintah daerah tidak akan mempublikasikan laporannya di website pemerintah daerah. Hal ini terjadi karena dapat mengurangi kepercayaan masyarakat. Dengan kepercayaan masyarakat yang berkurang akan menimbulkan ekspektasi bagi pejabat terpilih bahwa tidak akan dipilih diperiode berikutnya. Sebaliknya jika predikat audit wajar tanpa pengecualian maka pemda dengan sukarela akan menunjukkan laporan auditnya di internet.

\section{$\mathrm{H}_{3}$ : Opini Audit berpengaruh positif terhadap internet reporting}

\section{METODE PENELITIAN}

Subyek penelitian ini adalah pemerintah daerah level kabupaten/kota yang terdaftar pada website Kementrian Dalam Negeri (www.kemendagri.go.id) pada tahun 2018 dan pengungkapan laporan keuangan dan kinerja pemerintah (Internet Reporting) pada website-website. Jenis data yang digunakan adalah data sekunder. Data pengungkapan laporan keuangan dan kinerja Pemkot (Internet Reporting), Kekayaan daerah, Opini audit dan Predikat akuntabilitas Kinerja merupakan variable Independen pada penelitian ini. Data diperloleh dari lnternet Reporting melalui website Pemkot yang terdaftar di Kementrian Dalam negeri. Teknik pengumpulan data pada penelitian ini adalah Metode dokumentasi atau pengguanan data yang berasal dari dokumen-dokumen yang telah tersedia di website pemda masing-masing. Pengumpulan data dilakukan dengan melihat datadata yang dibutuhkan, mencatat, menganalisis annual report pada pemerintah kota tahun 2017.

Kompetisi politik merupakan variabel yang digunakan dalam mengukur seberapa besar peran politik dalam mempengaruhi administrasi pada pemda dan sebagai proki tersedianya informasi keuangan mengingat pertanggugjawaban pemda (Nosihana dan Yaya, 2016). Pada variable ini dapat diukur berdasarkan rasio jumlah anggota dewan partai non pendukung kepala daerah dengan jumlah seluruh anggota dewan dalam suatu pemda (Trisnawati dan Achmad,2014).

Sedangkan kekayaan suatu daerah dapat dilihat dari seberapa besar Pendapatan Asli Daerah (PAD) (Khasanah, 2014). PAD merupakan sumber dana yang diperoleh dari daerahnya sendiri serta menggambarkan potensi suatu daerah. 
Dalam hal ini Kekayaan daerah sendiri dapat diukur dengan total PAD suatu pemerintah daerah tersebut. Opini audit yang dikeluarkan oleh BPK dari laporan keuangan yang diberikan oleh seluruh pemda menjadi salah satu tolok ukur kinerja pemerintah (Trisnawati dan Achmad, 2014). Dengan demikian jika pemerintah daerah tersebut mendapatkan opini WTP maka akan semakin tinggi pengaruhnya dalam melakukan pengungkapan informasi keuangan dengan demikian akan memperlihatkan kinerja baiknya. Variabel dummy yang digunakan untuk mengukur opini audit tersebut adalah dengan 1 untuk Pemkot yang mendapatkan opini audit WTP dan 0 untuk Pemkot yang mendapatkan opini audit bukan WTP (Nosihana dan Yaya, 2016).

Sedangkan Internet Reporting dalam penelitian ini dimaksud sebagai pelaporan laporan keuangan dan laporan kinerja pemerintah daerah. Dalam mengukur tingkat pengungkapan, Komponen yang akan diteliti yaitu dihitung pada ketersediaan informasi laporan akuntabilitas kinerja pemerintah kabupaten/kota serta ditambah keuangan sesuai yang tertuang di dalam ketentuan Intruksi Mendagri Nomor 188.52/1797/SJ Tahun 2012 pada situs resmi setiap Pemda di Indonesia dan hasil maksimal 12 poin untuk setiap daerah (Nosihana dan Yaya, 2016). Berikut ini komponen yang di hitung untuk melihat internet reporting: 1) Ringkasan RKA SKPD; 2) Ringkasan RKP PPKD; 3) Rancangan Perda APBD; 4) Rancangan Perda Perubahan APBD; 5) Perda APBD; 6) Perda Perubahan APBD; 7) Ringkasan DPA SKPD; 8) Ringkasan DPA PPKD; 9) LRA SKPD; 10) LRA PPKD; 11) LKPD yang telah diaudit; 12) Opini BPK; dan 13)LAKIP. Pengujian hipotesis dilakukan dengan teknik analisis regresi berganda.

\section{HASIL DAN PEMBAHASAN}

Untuk mengetahui diskriptif setiap variabel pada penelitian ini digunakan analisis descriptive (Tabel 1). Jumlah sampel yang digunakan hanya 48 yang disebabkan masih banyaknya pemerintah daerah yang tidak melaporkan 13 informasi komprehensif mengenai praktik internet reporting yang disebutkan di atas.

Tabel 1. Statistik Deskriptif

\begin{tabular}{|c|c|c|c|c|c|}
\hline Variabel & $\mathbf{N}$ & Minimum & Maximum & Mean & Std. Deviation \\
\hline Kompetis & 4 & .08 & .91 & .6370 & .17644 \\
\hline i Politik & 8 & & & & \\
\hline Kekayaan & 4 & 20708500 & 417245739582 & 482277823551.4 & 776068706660.47 \\
\hline Daerah & 8 & 0 & 5 & 1 & 7 \\
\hline Opini & 4 & 0 & 1 & .88 & .334 \\
\hline Audit & 8 & & & & \\
\hline Internet & 4 & 3 & 13 & 8.67 & 2.612 \\
\hline Reporting & 8 & & & & \\
\hline Valid N & 4 & & & & \\
\hline (listwise) & 8 & & & & \\
\hline
\end{tabular}

Sebelum dilakukan uji hipotesis, peneliti terlebih dahulu melakukan uji kualitas data berupa uji normalita, Heteroskedastisitas, multikolinieritas, dan 
autokorelasi (Ghozali, 2011; Nazaruddin \& Basuki, 2017). Dari hasil uji kualitas tersebut semua asumsi terpenuhi, sehingga pengujian hipotesis dapat dilakukan. Ringkasan hasil analisis regresi linier berganda untuk uji hipotesis dapat disimak pada Tabel 2.

Tabel 2. Hasil Uji Regresi Linear Berganda

\begin{tabular}{lccccc}
\hline Variabel & Beta & t hitung & Sig t & Keterangan & Simpulan hipotesis \\
\hline Kompetisi Politik & 0.218 & 2.051 & 0.046 & Signifikan & $\mathrm{H}_{1}$ Diterima \\
Total Asset & 0.075 & 2.531 & 0.015 & Signifikan & $\mathrm{H}_{2}$ Diterima \\
Opini Audit & 0.371 & 2.308 & 0.026 & Signifikan & $\mathrm{H}_{3}$ Diterima \\
Adjusted R Square & 0.298 & & & & \\
\hline
\end{tabular}

Hasil penelitian ini menunjukkan bahwa Kompetisi Politik berpengaruh positif terhadap Internet Reporting Pemerintah Daerah. Kompetisi politik merupakan kompetisi yang bertujuan untuk memperoleh kekuasaan dalam mengendalikan pemerintahan dan mengalokasikan sumber daya yang tersedia untuk memenuhi kepentingan masyarakat maupun kepentingan politik. Kompetisi politik antara kepala daerah tidak lepas dengan campur tangan dari partai politik. Partai politik memiliki peran penting dalam penyelenggaraan pilkada. Peraturan yang mewajibkan calon kepala daerah harus diusung oleh partai politik menjadi tantangan besar di Indonesia. Hal tersebut mengakibatkan peningkatan kompetisi politik di Indonesia. Partai politik berkompetisi untuk mengusulkan calon kepala daerah (Bertot, 2010).

Kompetisi politik yang tinggi menimbulkan tuntutan mengenai transparansi informasi keuangan daerah juga akan semakin meningkat. Hal tersebut terjadi karena semakin banyak pihak yang memerlukan informasi tersebut untuk mengetahui keadaan pemerintahan terutama keadaan keuangan pemerintah daerah. Tuntutan dari berbagai pihak mengenai transparansi informasi keuangan daerah dapat dipenuhi dengan cara menyediakan informasi keuangan daerah pada website resmi pemerintah daerah. Penggunaan website sebagai media penyediaan informasi keuangan daerah dapat meminimalisir biaya yang dikeluarkan oleh pemerintah yang berkaitan dengan pengawasan yang dilakukan oleh masyarakat. Pemerintah daerah menginginkan untuk memiliki citra yang baik kepada masyarakat maupun pihak-pihak yang berkepentingan sesuai dengan teori signalling yang menjelaskan pemerintah sebagai pihak yang diberikan amanah kepada masyarakat yang berkeinginan menunjukkan signal kepada masyarakat. Tingkat kompetisi politik yang tinggi maka akan mendorong pemerintah daerah untuk menyediakan informasi keuangan daerah pada website resminya, sehingga dapat memenuhi kepentingan berbagai pihak (Andriani, 2009). Hasil penelitian ini sejalan yang dilakukan oleh Rahman (2013) yang melakukan penelitian serupa mengenai pengaruh kompetisi politik terhadap internet reporting pada tahun 2013 dengan sampel pemda mempunyai website yang dapat diakses. menyimpulkan bahwa kompetisi politik berpengaruh positif terhadap internet reporting. Semakin tinggi kompetisi politik, kecenderungan pemerintah daerah untuk menggunakan internet sebagai sarana pelaporan informasi keuangan yang mudah dan murah juga akan semakin tinggi. 
Hasil penelitian ini juga menunjukkan bahwa Kekayaan Daerah berpengaruh positif dan signifikan terhadap Internet Reporting Pemerintah Daerah. Tingkat kemakmuran suatu daerah dapat tergambarkan dari kekayaan daerah tersebut (Sinaga, 2011). Kekayaan daerah yang tinggi merupakan indikator kesuksesan suatu pemerintahan dalam mengelola potensi dan sumber daya yang dimilikinya, serta kesuksesan dalam hal mengelola keuangan. Pemerintah daerah yang mempunyai kekayaan yang besar, akan menunjukkan kinerjanya yang baik atas pengelolaan sumberdaya dan potensi daerahnya, serta semakin banyak informasi yang harus diungkapkan atas pertanggungjawaban kekayaan daerahnya yang besar. Sehingga pemda akan semakin banyak mempublikasikan laporan keuangannya di internet (Hudoyo dan Mahmud, 2014).

Kekayaan yang besar cenderung rentan terhadap penyalahgunaan. Hal inilah yang mendorong masyarakat selaku principal, menjadi lebih tertarik dalam mengawasi kinerja pemerintah daerah dan menuntut transparansi atas pengelolaan keuangan pemerintah daerah. Pemerintah daerah dengan kekayaan yang besar menanggung biaya pengawasan yang lebih tinggi dalam memenuhi tuntutan transparansi dari masyarakat. Melalui publikasi laporan keuangan, pemerintah daerah dapat menyampaikan informasi keuangan secara lebih lengkap dengan biaya yang lebih murah, sehingga dapat mengurangi asimetri informasi yang terjadi antara pemerintah daerah dan masyarakat (Hilmi \& Martani, 2012). Sesuai dengan teori signalling yang menyatakan pemda akan berusaha menunjukkan kepada masyarakat sebagai signal bahwa telah mengelola kekayaan daerah dengan baik. Hasil penelitian ini sejalan yang dilakukan oleh Hilmi dan Martani (2012) menyatakan bahwa kekayaan daerah berpengaruh positif terhadap tingkat pelaporan keuangan pemerintah provinsi. Peningkatan pengungkapan terjadi karena pemerintah provinsi memiliki kekayaan yang lebih besar yang dapat digunakan untuk melakukan pengungkapan. Dengan demikian jika terungkapnya kekayaan daerah pada pengungkapan, maka masyarakat akan memberikan kepercayaan mereka. Masyarakat tentunya akan berfikir bahwa pemerintah telah melaksanaan kewajibannya dengan baik.

Lebih lanjut, hasil penelitian ini menunjukkan bahwa Opini Audit berpengaruh positif dan signifikan terhadap Internet Reporting Pemerintah Daerah. Opini auditor merupakan pernyataan pemeriksa mengenai kewajaran informasi keuangan yang disajikan dalam laporan keuangan. Opini auditor merupakan salah satu indikator kualitas akuntabilitas keuangan dilihat atas penyajian Laporan Keuangan Pemerintah Daerah (LKPD). Opini audit secara bertingkat terdiri dari : Tidak Wajar (TW), Tidak Memberikan Pendapat (TMP), Wajar Dengan Pengecualian (WDP), dan yang terbaik adalah Wajar Tanpa Pengecualian (WTP) (Trisnawati dan Achmad, 2014).

Trisnawati dan Achmad (2014) menyatakan pemda yang mendapat opini WTP akan cenderung melakukan publikasi laporan keuangan melalui internet untuk menunjukkan sinyal kualitas pengelolaan keuangan yang baik dan dapat dipertanggungjawabkan. Sebaliknya, opini audit selain WTP dapat menimbulkan konotasi atau persepsi publik akan adanya penyimpangan dalam pengelolaan keuangan daerah, sehingga pemerintah cenderung menutupi informasi keuangannya. Opini WTP yang diterima pemda akan membuat pemda mempublikasikan laporan keuangannya di internet, untuk menunjukkan sinyal 
pengelolaan kualitas keuangan yang baik dan dapat dipertanggungjawabkan. Seperti teori signalling maka pemerintah akan memberikan sinyal kepada masyarakat bahwa keuangan daerah dikelola dengan baik. Hasil penelitian ini sejalan yang dilakukan oleh Hilmi dan Martani (2012) menyatakan bahwa Opini Audit memiliki pengaruh positif terhadap tingkat pengungkapan laporan keuangan. Dengan demikian pemda cenderung untuk memberikan informasi yang dimiliki di internet. Hal ini menunjukkan pemerintah memberikan signal kepada masyarakat bahwa telah melaksanakan amanah yang diberikan oleh masyarakat.

\section{SIMPULAN}

Penelitian ini bertujuan untuk mengetahui Determinan internet reporting pemerintah daerah di indonesia yaitu kompetisi politik, kekayaan daerah dan opini audit terhadap praktik internet reporting dengan menggunakan pendekatan regresi berganda. berdasarkan pengujian data, maka dapat disimpulkan kompetisi politik, kekayaan daerah dan opini audit berpengaruh signifikan positif terhadap internet reporting pemerintah daerah. Berangkat dari temuan ini maka implikasi pentingnya adalah pertama adalah suasana kompetesi politik penting untuk hadir dalam dinamika pemerintahan karena ternyata memiliki dampak positif yang baik terhadap praktik internet reporting. Namun demikian kompetesi politik yang dimaksud adal praktik yang sehat dan tidak melanggar norma serta etika dan berdemokrasi. Kedua, pemerintah daerah perlu untuk terus didorong untuk meningkatkan realiasasi potensi daerah dengan dicapainya PAD yang tinggi. karena kekayaan daerah ini akan menjadi bekal untuk melakukan praktik internet reporting sebagai manifestasi dari praktik transparansi dan akuntabilitas mengingat diperlukan biaya untuk menunjang kegiatan tersebut. Terakhir, pemerintah daerah perlu untuk selalu didorong dalam meningkatkan kualitas akuntabilitas pelaporan keuangannya dengan cara mengadakan pelatihan dan training untuk mencapai laporan keuangan yang baik (WTP). Hal ini agar berikutnya mendorong pemerintah daerah meningkatkan transparansi keuangannya kepada seluruh pemangku kepentingan melakui praktik internet reporting.

Penelitian ini tentunya memiliki banyak kekurangan. Diantaranya adalah jumlah sampel yang relatif sedikit. Hal ini dikarenakan masih banyaknya pemda yang tidak melakukan pelaporan reporting secara komprehensif yakni informasi kinerja keuangan dan non-keuangan. Berikutnya adalah terkait subyek riset yang hanya menggunakan pemda level kabupaten/kota. Berikutnya penting untuk melakukan riset sejenis pada pemda provinsi dan pemerintah pusat atau kementrian. Terkahir penggunaan metode riset lain sangat dianjurkan seperti kualitatif dan mixed method (triangulasi), agar pengkajian isu ini dapat menemukan temuan yang lebih kaya dan mendalam.

\section{DAFTAR PUSTAKA}

Andriani. Yelvina. (2009). Analisis Pengaruh Kompetisi Politik, Tingkat Pendidikan dan Jumlah Penduduk Terhadap Tingkat Pengungkapan Informasi Non Keuangan dalam Website Pemerintah Daerah Kabupaten dan Kota di Sumatera. Artikel Ilmiah. Padang: Fakultas Ekonomi Padang. 
Bertot, John C, Paul T. Jaeger, Justin M. Grimes. 2010. Using ICT to Create a Culture of Transparancy : E-government and Social Media as Opennessand Anti-corruption Tools for Societies. Government Information Quarterly. Vol 00659.

Connelly, B. L., Certo, S. T., Ireland, R. D., \& Reutzel, C. R. (2011). Signaling theory: A review and assessment. Journal of management, 37(1), 39-67.

Evans, J., dan J. Patton. 1987. Signalling and Monitoring in Public Sector Accounting. Journal of Accounting Research 25, pp. 130-158. http://www.jstor.org/

Febrianty S.Y., dan Jatmiko W.T. 2011. Analisis Faktor-Faktor yang Memengaruhi Pelaporan Keuangan di Internet Secara Sukarela Oleh Pemda.Jurnal Universitas Diponegoro. http://eprints.undip.ac.id/.

Ghozali, Imam., (2011), Aplikasi Analisis Multivariats dengan Program IBM SPSS 19, Cetakan 5, Badan Penerbit Universitas Diponegoro, Semarang.

Hilmi, A.K, dan Martani, D. 2012. Analisis Faktor-Faktor yang Memengaruhi Tingkat Pengungkapan Laporan Keuangan Pemerintah Provinsi.Simposium Nasional Akuntansi XV Banjarmasin.

Hudoyo, Y.T., 2014, "Faktor-Faktor Yang Mempengaruhi Pengungkapan Laporan Keuangan Di Internet Oleh Pemerintah Daerah", Accounting Analysis Journal 3 (4).

Khasanah, N.L., 2014, "Pengaruh Karakteristik, Kompleksitas, Dan Temuan Audit Terhadap Tingkat Pengungkapan Laporan Keuangan Pemerintah Daerah", Diponegoro Journal Of Accounting Volume 3, Nomor 3, Tahun 2014, Halaman 1-11

Nazaruddin, I., \& Basuki, A. T. (2017). Analisis Statistik dengan SPSS, Edisi Pertama, Cetakan Ketiga. Yogyakarta: Danisa Media.

Nosihana, Ariefia, dan Rizal Yaya, 2016, "Internet Financial Reporting dan Faktor-Faktor yang Mempengaruhinya Pada Pemerintah Kota dan Kabupaten Di Indonesia", Jurnal Dinamika Akuntansi dan Bisnis Vol. 3(2), 2016, pp 89-104.

Nurrizkiana, B., Handayani, L., \& Widiastuty, E. (2017). Determinan Transparansi dan Akuntabilitas Pengelolaan Keuangan Daerah dan Implikasinya Terhadap Kepercayaan Public-Stakeholders. Journal of Accounting and Investment, 18(1), 28-47.

Puspita, R dan Martani,D,. 2010. Analisis Pengaruh Kinerja dan Karakteristik Pemda terhadap Tingkat Pengungkapan dan Kualitas Informasi dalam Website Pemda.Jurnal dan Prosiding Simposium Nasional Akuntansi XV Banjarmasin.

Raharjo, Eko. 2007. Teori Agensi dan Teori Stewarship dalam Perspektif Akuntansi. Fokus Ekonomi. Vol. 2 No. 1 Juni 2007:37-46

Rahman, Aditya. Sutaryo. Agus, Budiatmanto, 2013, "Determinan Internet Financial Local Government Reporting di Indonesia”. Simposium Nasional Akuntansi XVI Hal. 129- 155, 2013. Manado.

Republik Indonesia. 2008. Undang-Undang No. 14. Keterbukaan Informasi Publik. Jakarta: Sekertariatan Negara.

Republik Indonesia. 2012. Instruksi Mendagri No. 188/1797/SJ. Transparansi Pengelolaan Anggaran Daerah. 
Sinaga, Y. F., \& TRI, J. W. P. (2011). Analisis faktor-faktor yang mempengaruhi pelaporan keuangan di internet secara sukarela oleh pemerintah daerah (Doctoral dissertation, Universitas Diponegoro).

Styles, Alan K., dan Mack Tennyson. 2007. "The Accessibility Of Financial Reporting U.S. Municipalities On The Internet". Journal of Public Budgeting, Accounting \& Financial Management, Vol. 19, No.1, hal.56-92.

Trisnawati, M,D., \& Achmad, K,. 2014. Determinan Publikasi Laporan Keuangan Pemda melalui Internet. Simposium Nasional Akuntansi XVII. Mataram. Lombok.

Buletin

APJII

https://apjii.or.id/downfile/file/BULETINAPJIIEDISI05November2016.pdf . (diakses tanggal 16 maret 2018) 